\title{
Umdala wethu legacy: The contested memories and the father- head role of Joshua Nkomo in Zimbabwe.
}

\author{
Richard Mahomva \\ Leaders for Africa Network, Zimbabwe \\ rasmkhonto@gmail.com
}

\begin{abstract}
This paper revisits the under-currencies of the normative and empirical motivations of the official iconic ornamentation of Joshua Nkomo's legacy during the Mugabe era. The urgency of this analysis is justified by how the ruling and Zimbabwe's former Head of State, Robert Gabriel Mugabe, strategically exploited the memorialization of Joshua Nkomo for political expedience. This was orchestrated through the state's Umdala wethu 'cultural nationalism' since 1999 as well as the infrastructural immortalisation of Umdala wethu in 2013. The state's monopoly over Nkomo's legacy competed with the anti-establishment and ethnicity inclined appropriation of Joshua Nkomo's legacy in the Matebeleland regions. One refers to this alternative and public consented appropriation of Joshua Nkomo's legacy as the traditional affirmative reposition of Father-Zimbabwe's political fatherhood in Zimbabwe's bodypolitic. Further, the paper posits that the clashing entitlements to Nkomo's legacy represents polarity of national memory in Zimbabwe.
\end{abstract}

Key Words: Umdala wethu, Joshua Nkomo, Robert Mugabe, legacy, cultural nationalism, immortalisation.

\section{Introduction}

Joshua Nkomo's fatherly effigy as Umdala wethu assumed a trendier status as Zimbabwe entered the Third-Chimurenga era following his death on the $1^{\text {st }}$ of July 1999. Nkomo's legacy received state officialisation which destabilised other forms of appropriations of his nationalist attributes which were essentially embraced by the people of Matebeleland who largely referred to him as "Umdala" (The Old man) and not so common as "Umdala wethu" (Our beloved old man/ Father) as witnessed after his passing-on in 1999. This was against milieu of Nkomo's archetypical role in nationalism from a more Matabeleland pronounced perspective in the nascent of the anti-colonial resistances which led to Zimbabwe's independence in 1980. Nkomo was a leading figure of the collective nationalist resistance to the Smith regime and thus assumed iconic nationalist accolades in the anti-colonial phase right up to postindependence (Nkomo, 1984). 
Joshua Nkomo's legacy epitomizes Zimbabwe's permanent national interests which emanate from the country's liberation struggle and the post-independence aspirations for democracy, peace, unity economic developments among other keynote principles of power architecture in Zimbabwe. Nkomo's celebrated statesmanship transcends the derogative victimization he was subjected to as the 'father of dissidents' during the Gukurahundi disturbances between 1982 and 1987. The shifting prominences of Joshua Nkomo's fatherhood in Zimbabwe's politics invites the need to understand why one who was the once labelled the father of dissidents rose to be 'Father Zimbabwe'. The first part of the chapter describes the tense political context in which Nkomo's credentials were manipulated to suppress the prominence of opposition politics (Barclay, 2011).

This paper explains how the era of 'crisis nationalism' catalyzed the rise of the alternative anti-state appropriation of the Umdala wethu legacy. Further, it is highlighted that state infrastructure challenged the public consented appropriation of Joshua Nkomo. To do so, the state instituted two apparatus. First was commemorative nationalism largely characterized by state sponsored galas as well as the officialisation of Nkomo's state as 'Father Zimbabwe' (Ndlovu-Gatsheni \& Willems, 2009).

\section{Crisis-nationalism and the resurgence the Umdala wethu legacy}

The economic challenges caused by Zimbabwe's land reform programme, the country's diplomatic fall-out with the West threatened the ruling's political base (Raftopolous \& Mlambo, 2009) On the other hand, the opposition had gained popularity which attracted intense state repression. During this period, there were numerous recorded cases of political violence. As a result, ZANU-PF revived the liberation rhetoric to re-establish its the relevance in the face of a growing opposition and a growing economic crisis. Ndlovu-Gatsheni (2011 p.5) argues that ZANU-PF strategically revived the Chimurenga ideology to secure its longevity:

The ideology of Chimurenga is deeply anti-colonialist. It began as part of nationalist innovation involving harnessing of pre-colonial and colonial historical moments to formulate an indigenous and vernacular conception of a nationalist revolution that linked primary resistance of the 1890s to the nationalist struggles of the 1970s. The ideology of Chimurenga is constantly being renewed by ZANU-PF leaders.

Just like the Chimurenga, Nkomo serves as an ideological beacon of the changing paradigms of Zimbabwe's political culture. This is why it was essential to evoke his role as Umdala wethu by ZANU-PF since he was a revered national icon whose acclaimed role transcended partisan lines. Nkomo's image resonated with 
Zimbabwe's divergent political groundings of the time since Nkomo is the pivot of national belonging in Zimbabwe for both the ruling and opposition political actors.

Hammar, Raftopolous and Jensen (2003) argue that the land reform predicament led to the emergence of narrow national consciousness whose premise was ZANU-PF's hegemony servicing through party manufactured patriotic memories and history (Ranger, 2004). It is for that reason that Umdala wethu legacy was evoked to rationalise this narrow nationalism.

\section{The traditional affirmative appropriation of the Umdala wethu legacy in the historical particularism of Matabeleland}

Ethnicity is a key feature in Zimbabwe's nationalist political landscape. While nationalist romanticism emphasizes a collective idea of belonging, ethnicity still shapes various narratives of nationalist entitlements in Zimbabwe. The role of ethnicity in framing the Zimbabwean discourse invites one to interrogate how the revival of Joshua Nkomo's legacy was initiated to appease Ndebele political particularism by the establishment in a bid to accrue political capital. The paper presents Matabeleland and largely Bulawayo, as the traditional affirmative appropriation spaces of Joshua Nkomo's legacy. This goes along with NdlovuGatsheni's (2008) submission on Ndebele particularism in the contemporary nationbuilding debate in Zimbabwe. Further, it affirms Mhlanga's (2012, p.212) proposition on the need for ethnicity to be understood as a crucial aspect of power architecture in modern African politics. He says,

A critical assessment of the instrumentalisation of ethnicity in most African states shows that it has often been the handmaid of nationalism. Ethnic group boundaries even though immutable, have a way of finding currency in conditions that would not have sparked their existence; thus impending any attempt aimed at understanding ethnicity as both a natural resource and an object of premordiality with a strong nativist clause.

Ethnicity and its link to Zimbabwe's political culture informing this paper validates the need to investigate why Nkomo was not 'highly' celebrated using deep Shona political cultural connotations that have been the traditional source of ZANU-PF's historical premise for political cogency. This position is key in asserting the extent to which villagism and provincialisation of the national discourse has been strategically manipulated by political parties in pursuit of their hegemonic interests. At the same time, ethnicity has also constructed feelings of solidarity among those who see themselves as cultural and historical commons in defining their own political cause for and against the centre of power. Basing on that point, it can be argued that there 
was need to express some Kalanga cultural peculiarity in the reconstruction of Nkomo's image in Zimbabwe's contemporary politics. This proposition is justified by Nkomo's life story which explains his intense indulgences linked to BuKalanga cultural socialization. He says,

As the spirit of Zimbabwean nationalism came to the fore again in the early 1950 `s, I examined for myself the power of the traditional faith of my people, and visited the shrine where Mwali resides in the Matopo hills. Well before dawn, at about 3a.m., William Sivako and Grey Mabhalani Bango, the nephew of the chief of my father`s village, accompanied me to the place called Dula. (Nkomo, 1984, p.13)

Therefore, it would have made sense if a Kalanga expression of Umdala wethu was included in ZANU-PF's authenticity hunt through the person of Joshua Nkomo in 1999. The above excerpt from Nkomo's memoir proves that his political career path could also be traced to Kalanga spirituality which is excluded in the framing of liberation theologies in the public discourse. The sacred place which Nkomo referred to as "Dula" is part of the Kalanga spiritual heritage which served a similar function as that of Njelele in the Kalanga spirituality.

Njelele is a 'Mwari shrine located on a hill known by its Kalanga name Njelele in Matobo. Legend has it that the name emanates from ancient migratory 'njerere' birds that beckoned coming of the wet season. With most of the Matojeni shrines having become inactive Njelele has emerged in the last four decades as the principal Mwari shrine. Other shrines in the Matojeni landscape include Dula, Zhilo, Wirirani and Manyangwa (Murambiwa, The Patriot 16 April 2014). ${ }^{l}$

Sibangilizwe Nkomo, Chairperson of the Joshua Nkomo National Cultural Movement and son to Joshua Nkomo, highlighted that his family has a Sotho ancestral background. He notes that,

Nkomo's Grandparents were not Kalanga. They were Sotho. However, they were absorbed into the Kalanga Society. Automatically they became Kalanga by absorption. This is what happens with us Africans, when one lives among a particular group of people they assume their cultural practices. This is why in his book he talks about the Dula shrine associated with the Kalanga tradition. The Kalanga have also belonged to the nation of Mthwakazi and this is what made Nkomo to be viewed as more of a

${ }^{1}$ Murambiwa I. Njelele and Mwari Religion. The Patriot. 16 April 2014. 
Umdala wethu legacy: The contested memories and the father-head role ...

political custodian of the Ndebele people though he was 'Father Zimbabwe ${ }^{2}$.

Using the evidence above, one is justified to argue that Nkomo's legacy reimagination would also have been more meaningful had it acknowledged his Kalanga socialisation. This could have strategically captured the influence of the Kalanga traditions in shaping his connection to nationalism. This is proved by his induction to African nationalism from a Kalanga spiritual influence from the sacred Dula shrine as narrated in the above extract of his biography.

Contrary to that expectation, the government gave Nkomo's legacy a Ndebele ethnolinguistic appraisal "Umdala wethu." Sibangilizwe Nkomo further argues that this may have been drawn from the fact that one of Joshua Nkomo's grandfathers (Mqabuko) whom he was named after, was a Ndebele political elite who served in the Ndebele state's army. Sibangilizwe Nkomo states that the name "Mqabuko" was Joshua Nkomo's official title as he was vested with the mandate to pursue anticolonial military resistance. His contribution to nationalism in his progressivelyNdebele approach.

Therefore, it was not only politically strategic for ZANU-PF to be emphatic on Nkomo's progressive-Ndebele political credentials, but it was also historically correct. It is that history which was crucial in the forging of nationhood whose contestations further shaped the country's political crisis. This makes it pivotal to investigate the deeper historically embedded motives of ZANU-PF's exploitation of Father Zimbabwe's Ndebele-centred nationalist attributes. One of these being the title, Umdala wethu which as explained earlier suggests the Ndebele people's embracement of Nkomo's paternal figure to them. This nationalised attribute to Nkomo serves as a public proclamation of his role as the father of the Zimbabwean citizens. The use of this Umdala wethu title in reference to Nkomo demonstrates how ZANU-PF was using the image of Nkomo to re-engage the Ndebele in its cohesive nation-making prospects marred by historical antagonism.

Ndlovu-Gatsheni (2008) argues that one of the crucial challenges faced by ZANU-PF in its interest to assert political relevance guided by radical essentialism was Ndebele particularism. This explains why Nkomo's image has been appropriated by ZANUPF in an apologetically Ndebele manner to show a sense of cordial appreciation of the Ndebele as equals of the post-independence elites belonging to the ruling Shona party, ZANU-PF. On the other hand, Matabeleland as an area of ZANU-PF's political interest required the party to establish an image that transcends its Shona

2 Interview: Sibangilizwe Nkomo. 9 November 2015, Bulawayo. The interview was conducted at Nkomo's Blue Lagon Business Complex. The place is also called Ko-Mdala in remembrance of $\mathrm{Dr}$ Joshua Nkomo. 
predominance and essentialism. Therefore, the adoption of the Umdala wethu legacy over the years resonates with ZANU-PF's political interest in Matabeleland. This is influenced by some ethnic consciousness drive from civil society and radical intellectual propositions propagating the idea of Matabeleland as a nation within a nation.

In this context, 'Matabeleland' specifically refers to the country's provinces which have been predominantly Ndebele since the colonial period until the postindependence era. This does not exclude other groups such as the Tonga and the Kalanga found in Matabeleland. Such ethnic minorities found in Matabeleland constitute the inclusive elements of Ndebele particularism in this discussion.

The revival of Umdala wethu legacy by ZANU-PF at the beginning of the millennium was a strategic confrontation and mapping a negotiation pathway with Ndebele particularism. It was a direct attack on the ethnic political consciousness of the people of Matabeleland whom at some point in history were the vanquished and vulnerable group of post-independence Zimbabwe. This was part of ZANU-PF's aim of creating a de-facto one-party state (Mandaza \& Sachikonye, 1991). It was strategic for the ruling government to claim a share of the legacy since Nkomo was the modern pinnacle of this ethnic essentialism. To some extent, this gave a well-rehearsed act of reconciliation between the state and the Ndebele. This followed a background of Gukurahundi atrocities perpetuated by the ruling ZANU-PF in Matabeleland. This is why Nkomo was detached from the normative homogenous feeling of nationhood that ZANU-PF advocating for since 1980,
Robert Mugabe had decided to have me out of the way, and he did not evidently care what method was used. But I hold the legitimate Government of Zimbabwe innocent of this atrocity. Mugabe was not acting as prime minister, but as leader of his party, Zanu. I had once asked him directly: 'What is the supreme organ in Zimbabwe?' He answered: The supreme body in Zimbabwe is the central committee of Zanu (PF), my party (Nkomo, 1984, p.3).

The above suggests that at some point Nkomo disassociated himself from the ZANUPF model of post-colonial nation building. The post-independence conflict which is accounted for in Nkomo's memoir also captures the long grudges between nationalist movement particularly how ZANU-PF emerged as a faction from Nkomo's Zimbabwe African People's Union (ZAPU) in 1963 (Ranger, 2013). Since then, Nkomo's role as the father of Ndebele particularism reached a high turning-point. This is confirmed by Msindo (2007) who argues that the politics of ethnicity in Matabeleland and largely in Bulawayo was crucial in defining the broader context of nationalism in Zimbabwe. His study focuses on the magnitude of Ndebele ethnic 
consciousness in Bulawayo and how it was vital in shaping Ndebele inclined propositions to the discourse of African political awakening which later contributed to the broader African anti-colonial awakening of the Second-Chimurenga. Moreover, Nkomo's early nationalist campaigns in Bulawayo as a trade-union leader cannot be avoided in this analysis. Hence his continued resurfacing in Zimbabwe's political environment.

From the foregoing, one also notes that the Umdala wethu legacy has its roots in the preservation of Ndebele particularism which since 1893 contested colonial supremacy under the British South-African Company (BSAC) administration. This is the same political particularism that had influenced the establishment of the Ndebele state. This further explains why the Ndebele version of the popularised Chimurenga was called Umvukela. The term 'armed resistance' was a unique Ndebele colonial armed resistance between 1896 and 1897. Therefore, when Nkomo participated in the nationalist struggle against colonialism on a more "progressively-Ndebele" stance as posited by Nyathi (2015). He assumed the title Umdala from the Ndebele. Likewise, Nyathi (2015) further argues that Nkomo was affectionately embraced as Umdala by most pro-active supporters of his political operations in the $1960 \mathrm{~s}^{3}$. In a different interview, Sibangilizwe Nkomo confirmed this assertion,

Most people called my father "Umdala" which means Old man. This title showed that he was a respectable figure. Even some people who were older than him called him "Umdala" and that was a sign of respect. One of my father's companions once remarked: 'uNkomo uphethe into ezindala yikho simuthi nguMdala' (Nkomo is a bears old burdens this is why we call him 'the old man'). It is only now that we hear more of Umdala wethu this and that, again he was never Nyongolo. It is a taboo in our culture for a child to take up their father's name especially if they are to use it as an office name. Instead his real office name was Mqabuko, his grandfather's name. You are only allowed to inherit your grandfather's name. It was certain politicians who decided to call him Nyongolo and use the title Umdala wethu for their own reasons. This is because they wanted a sense of ownership to his legacy and they achieved in making Umdala (the Old man) theirs.

This may also imply that the struggle for liberation was grounded on particular ethnicity interests which were linked to some nationalist leaders. Therefore, Nkomo was the representation of Ndebele particularism though his credentials in the build up to independence transcended these narrow framings of his legacy. However, this did not delink him from the base of his political home ground which was Matabeleland where he was embraced as Umdala/ Umdala wethu and yet beyond Matabeleland he

3 Interview: Pathisa Nyathi. 9 September 2015 at the National Gallery in Bulawayo. The interview focused on making historical sense of the Umdala wethu legacy and locating it within historical parameters. 
was Father Zimbabwe. These regional and national paternal attributes attached to Joshua Nkomo represent his interchanging fatherly surrogacy to Zimbabwe's contemporary political culture. As confirmed by Sibangilizwe Nkomo above, this justifies why ZANU-PF also personalised Nkomo's legacy to legitimize its social integration agenda.

The fatherly attributes of Nkomo to the birth of Zimbabwean nationalism are complimented by ethnic political consciousness which informed the social-contract of the Second-Chimurenga. Therefore, when he is called Umdala wethu it is important for one to draw lessons on how his role in the nationalist era defined pertinent ethnicity particularities in Zimbabwe's liberation war which are drawn into the contemporary political landscape for partisan legitimacy contestations. There is need to appreciate the Umdala wethu legacy against a background of Ndebele-centred feelings of political marginality emanating from the mandate carried by ZAPU in being "progressively Ndebele." This does not dismiss Nkomo's role as the nation's figure of unity in the quest for liberation. However, that standpoint was a reciprocation to the progressively Shona approach applied by ZANU-PF and its military wing the Zimbabwe National Liberation Army (ZANLA),

\begin{abstract}
Zipra and Zanla were very different armies. Zipra, based in Zambia and operating into Rhodesia across the Zambezi, was organized purely as a fighting force under strict military discipline and political control. Zanla, on the other hand, had combined military action with political indoctrination. The terrain along the border between Mozambique and Zimbabwe allowed them much more freedom of movement (Nkomo, 1984, p.202).
\end{abstract}

This divided approach to the struggle earned Nkomo the title Umdala/ Umdala wethu from his supporters (largely the Ndebele and non-Ndebeles who sympathised with ZAPU) who accorded him the status of being a vanguard of Ndebele particularism and decolonisation. This further explains why ZANLA and ZIPRA forces expressed hatred towards each other through violence (Bhebe, 2004). Even towards the elections that gave birth to Zimbabwe, ZIPRA supporters were subjected to violence from ZANU-PF's ZANLA military wing,

We received reports of unidentified bands of armed men speaking Portuguese, who raided communities that had hitherto been faithful to Zapu, beating or even killing Zapu party organizers, and compelling the people to shout slogans of which the clearest was `Down with Nkomo. Even before the cease-fire, when all energies should have been concentrated on defeating the Smith regime, Zanu was building up its political organization in eastern Zimbabwe, along the Mozambique border (Nkomo, 1984, p.204). 
This "institutionalisation of violence" (Sachikonye, 2011) largely advanced by ZANU-PF's 'progressively Shona' approach to amassing power, made Nkomo to be viewed as the beloved father of the victims of political violence. Nkomo openly castigated violence that emanated from ZANU-PF's Shona tribal prejudices and that buttressed his nationalist fatherly attributes to the disenfranchised Matabeleland. The appropriation of Nkomo's image in the discourse of Ndebele particularism is premised on his sustainable peace building volition for the real attainment of liberation goals. The construction of Nkomo's image as the father of peace is guided by the view that he offered constructive reactions to the culture of violence which was aimed at subduing his nationalist credentials. This is why the victims of the violence perpetuated by ZANU-PF would eulogize Nkomo as their beloved father who retaliated violence with diplomacy.

Nkomo remained consistent on the idea of building a peaceful Zimbabwe even after the ostracised Gukurahundi operation of 1982 by ZANU-PF of exterminating dissidents coupled with civilian brutality and murder in Matabeleland (Stiff, 2000). This is evidenced by his willingness to sign the Unity Accord of 1987 which ended the Gukurahundi. The Gukurahundi has been perceived as an ethnic genocide that was aimed at dismantling Nkomo's support base in Matabeleland. It is from that view, that it remains crucial to understand Nkomo's role as the source of Matabeleland's post-colonial immiseration and self-assertion. Regardless of the political turbulence faced by Matabeleland for its particularism, Nkomo has remained a fatherly darling to this cause of ethnic consciousness. President Mugabe once called him the "father of the dissident party" referring to ZAPU which deserved "utter destruction." This reflects how much Nkomo has been institutionally accorded the fatherly symbol for Matabeleland though in some cases it served as a means of denigration of his person.

Surprisingly, the same denigrators of his person as the "father of dissidents" have also appropriated his fatherly credentials to Matabeleland to harness legitimacy for their contemporary political ambitions. On the other hand, there has been hyped ethnic national consciousness of the people of Matabeleland as they have used the fatherly surrogacy of Nkomo as a citadel of self-assertion in interacting with the ruling government. This has been justified by their political and social marginalisation out of which a form of regional consciousness has emerged within the context of what Paulo Freire (1970) called the "Pedagogy of the Oppressed." This is why Nkomo has been affectionately embraced as Umdala wethu by the people of Matabeleland as he bore the burden of confronting the ruthless moments of national anarchy in the form of the infamous Gukurahundi. This makes Joshua Nkomo an unavoidable narrative icon of the Ndebele's moments of trials, triumphs and desire for continuity. This is why all political parties and political discourse drivers interested in gaining relevance in Matabeleland, have associated their varying initiatives with the person of Joshua 
Nkomo. This is evident that his legacy is the foundation and definition of being Zimbabwean in all its contested forms.

\section{The state and the appropriation of Umdala wethu}

The state's appropriation of Joshua Nkomo's legacy was a crucial commodity for ZANU-PF's expedience. ZANU-PF's official acknowledgement of Nkomo's fatherly role to Zimbabwe nationalism in the manner discussed here avidly captures the extent to which Nkomo's legacy is a motif of unity and nation-building. In a way, this marked a deliberate and systematic forgetting of the sequestration that Joshua Nkomo experienced during the hostile Gukurahundi era.

Therefore, Joshua Nkomo's endeared fatherly status in Matabeleland and in the entire country in general prompted ZANU-PF to appropriate his legacy in a bid to articulate national interest in a crisis political situation. Joshua Nkomo's supra-nationalist stature validates the state's official resurrection of his memory in the face of brutal opposition aiming at dismantling the centrality of ZANU-PF in Zimbabwean politics.

In the same manner, Nkomo is a semiotic representation of anti-state representation around discourses of the rift between the state and polemic Matabeleland political postures. This brings to the fore Joshua Nkomo's relevantly interchanging and luminary fatherly symbol to Zimbabwe's political culture since the quest for self-rule of the African and the attainment of exactly that after 1980. This further indicates Nkomo's supra-nationalist credentials which transcend partisan tags as noted by how ZANU-PF has arrogated and protagonised his image to locate its agenda among varying sections of the population especially in Matabeleland where it is infamous on the grounds of historical grievance.

On the other hand, it is historically justified to use ZANU-PF as a conceptual point of reference to the marginal political appropriation of the Umdala wethu legacy. Chief among the reasons being the party's historical credibility in defining the winding courses of the aspirations of nationalism in Zimbabwe since the inception of the popular liberationist trajectory that brought independence. ZANU-PF belongs to the past and the present of Zimbabwe's political culture. Unlike other new political institutions like the MDC whose role only has contemporary relevance that dismisses the past, ZANU-PF is better positioned to be the centre of analysis as far as the legacy appropriation of Umdala wethu is concerned. This is why Joshua Nkomo's fatherly role to the nation could only be manipulated by ZANU-PF for propaganda in the face of crisis-nationalism.

This position affirms the submission by Alexander, McGregor and Tendi (2013), who argue that ZANU-PF under Robert Mugabe thrived on its intimate connection to the 
nationalist history, symbols and icons and in the process it accrued a generous measure of political patronage. During the Mugabe-era history was at the centre of the state's assertion to power to challenge the emerging anti-thesis of neo-liberal political predisposition of the opposition (Hammar, Raftopolous \& Jensen eds. 2003). This was also influenced by how the opposition had -and still has disassociated itself from the nationalist legacy. In return, this incentivized ZANU-PF with a comparative advantage in reclaiming Joshua Nkomo's legacy for expedience.

\section{The Umdala wethu Gala and Cultural nationalism}

This parochial appreciation of national legacies by other political actors enabled Mugabe's ZANU-PF to find comparative lodgment in Zimbabwe's political culture space. Mhiripiri (2012) considers the introduction of national Galas as one method used by ZANU-PF to polarise Zimbabwe's crisis-nationalism. One of these was the Umdala wethu Gala which was introduced by ZANU-PF to celebrate the life of Joshua Nkomo. The celebration of Nkomo's legacy through galas was short-lived and that substantiates how the Umdala wethu gala was a political project aimed at mobilizing the nation's support towards the temporary propaganda interests of ZANU-PF. The state through the Ministry of Information and Publicity convened the galas between 2000 and 2006. Thereafter, the Umdala wethu galas were suspended from the national calendar and this indicates how these galas were political projects as they considering the lack of posterity in the country's political calendar. It is clear that the narrow consistency in the commemoration of Nkomo's fatherly role and contribution to the nation was meant to serve Mugabe's sectorial interests. NdlovuGatsheni and Willems $(2009$, p.16) have argued that this marked the rise of cultural nationalism which served as a "movement of moral regeneration projected at reuniting "the different aspects of the nation - the traditional and modern, agriculture and industry, science and religion - by returning to the creative life-principle of the nation." The appropriation of Nkomo through "cultural-nationalism demonstrated the path of a failed regime in regenerating nationalism through establishment guided commemorations. Cultural nationalism as a process offers a public admiration of nationhood basing on simplistic notions of belonging for instance commemorating the life of a national figure. This kind of belonging to the nation does not translate to political-economy development. This analysis is set within the context of the ThirdChimurenga here summarised as an era of crisis-nationalism. This progress drawback political epoch was galvanised by commemorations of icons like Nkomo as indemnity for state failure as discussed above. The galas became a significant element of ritualising a dilapidating nationalism from a ZANU-PF point of view:

Galas are part of a government calendar of commemorative music concerts. They are organized in honour of an historic event or public holiday such as the Independence Day Gala, the Heroes Splash and the 
Unity Gala, or they may commemorate a national figure such as the two late Vice Presidents, Simon Muzenda and Joshua Nkomo, who were honoured by the Mzee Bira and the Umdala wethu Gala. 'Galas' are associated with ZANU-PF as they are organized under the auspices of the openly partisan Ministry of Information and Publicity (Mhiripiri, 2012, p.9).

Mhiripiri's (2012) view above clearly defines the national galas as highly political commemorative events in pursuit of ZANU-PF's political interests. This is why the Umdala wethu Gala was an essential official state endorsement of Joshua Nkomo's fatherly surrogacy to Zimbabwe. This marked a well calculated premier political appropriation of Joshua Nkomo's legacy as confirmed by Sibangilizwe Nkomo in the interview, that,

Galas are alien to us. In our culture it is not known to celebrate a person in the manner some politicians have decided to celebrate the life of my father. The truth of the matter is that some politicians saw profit in my father's legacy and that is why they personalised him after declaring him a national hero they made him their; hence the Umdala wethu Gala. When they 'appropriated' Nkomo's name as you put it they saw profit. The galas were political profiteering initiatives and not a sign of respect to Joshua Nkomo. They were not!

The submission by Silibangilizwe Nkomo in the interview confirms the key argument of this study which doubts that it was Nkomo's life that was being celebrated through the galas. Instead there was more of political interests of the government being served using Nkomo's name through such platforms. Mhiripiri goes further to confirm Sibangilizwe's view on galas as an alien element to what Joshua Nkomo embraced from a cultural and ideological point of view. This is because the galas appeared more as a revival of the Pungwe ceremonies linked to Shona cultural wartime assembles of music, dance in boosting liberation morale and promoting civilian-military consciousness of the armed liberation war (Pongweni, 1982). This further explains why the first Pungwe after independence was in Zimbabwe's Shona capital of Harare,

Government has always been involved in the organization and promotion of such events, starting with the 18 April 1980 independence celebration at Harare's Rufaro Stadium. That was probably the first large-scale pungwe in post-independence Zimbabwe, with Bob Marley as the highlight (Mhiripiri, 2012, p.9).

Sibangilizwe Nkomo disregards the significance of the Umdala wethu Galas that were convened consecutively between 2000 and 2006. Sibangilizwe Nkomo argues that 'the galas were ZANU-PF's tool to attract support from the people of 
Matabeleland". In the same interview, Sibangilizwe further states that the galas were key in servicing a ZANU-PF centred nationalism, “... the galas were never about national interest, they were about ZANU-PF's self-preservation against the opposition." While these contradictions are inevitable, Joshua Nkomo is a relevant fatherly symbol of Zimbabwean politics and his legacy transcends the monopoly of the state to its place in the biography of nationalism.

\section{The infrastructural immortalisation of Umdala wethu}

The political appropriation of the Umdala wethu legacy also goes beyond cultural nationalism. The second aspect of Umdala wethu preservation entails his immortalisation through infrastructural development in Bulawayo. The main reason being that Bulawayo is a centre of Nkomo's early political influence that cascaded to the final phase of national mobilisation for the liberation war of Zimbabwe. Likewise, Bulawayo was Nkomo's political powerbase and the city's political culture represents that perspective. Regardless of this Nkomo has remained a timeless City-father of Bulawayo whose political role has been used to shape the direction of the rift between ZANU-PF and Bulawayo.

This was mainly characterized by the mushrooming of Civic Society Organisations (CSOs) whose interest was to give a political alternative to the set establishment political culture (Mathema, 2013). These CSOs have also popularised the idea of Matabeleland being deliberately marginalised by the state. In line with this perspective, Muchemwa (2014, p.8) presents a thesis of hydro-politics in Bulawayo and argues that "issues of water supply particularly the uneven distribution of water in the high density suburbs of Bulawayo is part of a structured and deliberate mechanism to "discipline the dissident city."

It is on the basis of the above reasonable circumstance that one understands the reason behind the infrastructural immortalization of Joshua Nkomo. This was clearly a hegemonic exercise by ZANU-PF to consolidate power in Bulawayo. This process was executed through the renaming of the then Bulawayo International Airport as the Joshua Mqabuko Nkomo International Airport. The renaming of the airport in Bulawayo was synonymous with the erection of the Joshua Nkomo statue. This statue was erected in the heart of Bulawayo's former 'Main Street' now named Joshua Nkomo Street. This lucidly substantiates Nkomo's fatherly role to Zimbabwean politics and how his supra-nationalist credentials represent a source of legitimacy for political parties. This further points out Joshua Nkomo's unifying fatherly character in Zimbabwe's contested national question. 


\section{Conclusion}

The paper discussed how the Umdala wethu legacy has been manipulated in the mainstream political discourse in Zimbabwe. The paper also traced the iconic role of Joshua Nkomo in shaping Zimbabwe's political culture and all the contestations surrounding it. The continued resurfacing of Nkomo's legacy to explain Zimbabwe's various political turning points also defines the perpetuity of his statesmanship our politics. In the process, this political and ideological omnipotence remains a benchmark to conceptualizing the contested entitlements to the Umdala wethu legacy. The dichotomies of Joshua Nkomo's political fatherly surrogacy to Zimbabwe substantiate that Joshua Nkomo was and is still the centre of our national consciousness which in this modern day is in a problematic state of self-definition. This is why ZANU-PF has continued to regenerate the legacy of Joshua Nkomo to gain political relevance following its contribution to the present-day 'crisis nationalism' which it rebutted with cultural nationalism. To this end, ZANU-PF has employed the infrastructural immortalisation of the Umdala wethu legacy in order to give itself an endless attachment to the values of Nkomo which add to the long awaited 'real nationalism' in Zimbabwe opposed to the crisis nationalism that has facilitated the decline of the country's political-economy.

\section{REFERENCES}

Barclay, P. 2011. Zimbabwe: Years of Hope and Despair. London: Bloomsbury Paperbacks.

Bhebe, N. 2004. 'The Golden Age of Zimbabwe's Historiography and Its Decline from 1967 to the Present', The Dyke: The Journal of Midlands State University, 1(1), pp. 15-38.

Freire, P. 1970. The Pedagogy of the Oppressed. London: Continuum.

Hammar, A., Raftopolous, B. \& Jensen, S. (eds.) (2003). Zimbabwe's Unfinished Business. Re-thinking Land, State and Nation in the Context of a Crisis. Harare: Weaver Press.

Mandaza, I. \& Sachikonye, L. 1991. 'Introduction: The Zimbabwe debate on the oneparty state and democracy' in Mandaza, I. \& Sachikonye, L. (eds.) The One Party State and Democracy: The Zimbabwe Debate. Harare: Southern Africa Political Economy [SAPES Books] Trust.

Mhiripiri, A. 2012. 'Dancing through the Crisis: Survival Dynamics and Zimbabwe Music Industry.' In Mudimbe, V. (ed.) Contemporary African Cultural Productions. CODESRIA: Dakar. 
Umdala wethu legacy: The contested memories and the father-head role ...

Mhlanga, B. 2012. 'Devolution-'the ticklish' subject: The 'Northern Problem' and the national question in Zimbabwe.' Ubuntu 1(1). pp. 212-234.

Msindo, E. 2007. 'Ethnicity and Nationalism in Urban Colonial Zimbabwe: Bulawayo, 1950 to 1963.' Journal of African History. 48. pp.267-90.

Musemwa, M. 2014. Water, History and Politics in Zimbabwe: Bulawayo's Struggles with the Environment, 1894-2008. Africa World Press.

Ndlovu-Gatsheni, S. 2008. 'Nation-Building in Zimbabwe and Challenges of Ndebele Particularism,' African Journal on Conflict Resolution, 8, (3). pp. 27-56.

Ndlovu-Gatsheni, S. \& Willems, W. (2009) 'Making sense of cultural nationalism and the politics of commemoration under the Third Chimurenga in Zimbabwe.' Journal of Southern African studies, 35(4) pp. 945-965.

Ndlovu-Gatsheni, S. 2011. 'The Construction and Decline of Chimurenga Monologue in Zimbabwe: A Study in Resilience of Ideology and Limits of Alternatives' (Paper Presented at 4th International European Conference on African Studies (ECAS 4) on the Theme: African Engagements: On Whose Terms? Held at Nordic Africa Institute, Uppsala, Sweden, 15-18 June 2011). (Accessed 7 June 2013)

Nkomo, J. 1984. The Story of my Life. London: Methuen.

Pongweni, A. 1982. The Songs that Won the Liberation War. College Press, Harare.

Raftopoulos, B. 2002. 'The Labour Movement and the Emergence of Opposition Politics in Zimbabwe', in B. Raftopoulos \& L. Sachikonye (eds.) Striking Back: The Labour Movement and the Postcolonial State in Zimbabwe. Weaver Press, Harare.

Raftopoulos, B. \& Phimister, I. 2004. 'Zimbabwe Now: The Political Economy of Crisis and Coercion.' Historical Materialism, 12 (4) pp. 355-382.

Raftopolous, B. \& Mlambo, A. 2009. Becoming Zimbabwe. Harare: Weaver Press.

Raftopolous, B. 2013. 'The 2013 Elections in Zimbabwe: The End of an Era.' Journal of Southern African Studies. 39(4), pp. 971-988.

Ranger, T. 2004. 'Nationalist historiography, patriotic history and the history of the nation: The struggle over the past in Zimbabwe.' Journal of Southern African Studies. 30(2) pp. 215-234. 
Richard Mahomva

Ranger, T. 2013. Writing Revolt: An Engagement with African Nationalism 1957-67. Harare: Weaver Press.

Sachikonye, L. 2011. When a State Turns on its Citizens. Harare: Weaver Press.

Stiff, P. 2000. Cry Zimbabwe-Twenty Years On. Johannesburg: Galago Publishing. 